\title{
Special Section
}

\section{Sexually transmitted proctitis}

\author{
Sidney Roberto Nadal ${ }^{1}$, Carmen Ruth Manzione ${ }^{2}$ \\ ${ }^{1}$ Full professor of General Surgery; Supervisor of the Technical Team of Proctoloty at Instituto de Infectologia Emilio \\ Ribas - São Paulo (SP), Brazil. ${ }^{2}$ PhD in General Surgery; Proctologist in the Technical Team of Proctology at Instituto de \\ Infectologia Emílio Ribas - São Paulo (SP), Brazil.
}

Nadal SR, Manzione CR. Sexually transmitted proctitis. J Coloproct, 2012;32(1): 95-7.

\begin{abstract}
Proctitis caused by sexually transmitted agents is usually taken for inflammatory bowel diseases, because of similar complaints, such as pain, bleeding and mucopurulent discharge, as well as the histopathology. Thus, its treatment is postponed and, sometimes, complications appear. The most common etiologic agents are Neisseria gonorrhoeae, Chlamydia trachomatis, Treponema pallidum and Herpes simplex. In order to avoid dissemination and complications, laboratory tests are essential for diagnosis and proper therapy. The objective of this article was to raise awareness to sexually transmitted diseases in proctitis etiology, as well as their diagnosis and treatment.
\end{abstract}

Keywords: proctitis; sexually transmitted diseases; diagnosis; therapy.

RESUMO: As retites provocadas por agentes sexualmente transmissíveis são frequentemente confundidas com doenças inflamatórias intestinais, uma vez que as queixas mais comuns, que incluem dor, sangramento e secreção mucopurulenta, e o padrão histopatológico são semelhantes. Dessa maneira, o tratamento é postergado e, algumas vezes, as complicações aparecem. Os agentes mais comuns incluem a Neisseria gonorrhoeae, a Chlamydia trachomatis, o Treponema pallidum e o Herpes simplex. Exames laboratoriais sensíveis e específicos para confirmação diagnóstica são essenciais para o tratamento correto, evitando a disseminação e as sequelas. O objetivo deste artigo foi chamar a atenção para as doenças sexualmente transmissíveis na etiologia das retites, bem como seu diagnóstico e tratamento.

Palavras-chave: proctite; doenças sexualmente transmissíveis; diagnóstico; terapia.

Sexually transmitted diseases (STD) are still a major public health issue. Their incidence is increasing worldwide, despite the prevention campaigns, favoring the contamination by the human immunodeficiency virus (HIV) ${ }^{1}$. The anorectal location is common, especially among males who have sex with males (MSM), and unprotected anal receptive sex is the most likely cause ${ }^{2}$. However, these diseases can also be observed in male and female heterosexuals, and the transmission can be due to other sexual practices, such as the oral-anal and anal-genital contact ${ }^{1}$. Also, increasing sexual risk behaviors have been noticed in the past few years, which led to the reappearance of older infections, such as syphilis, and the appearance of new ones, considered to be unknown in developed countries, such as venereal lymphogranuloma, especially as proctitis ${ }^{1}$.

Proctitis is usually diagnosed as an inflammatory bowel disease ${ }^{2}$, once the most frequent complaints consist of pain, bleeding and mucopurulent discharge ${ }^{3}$; besides, histopathology is similar ${ }^{4}$. Due to these reasons, sexual transmission is not considered. Thus, treatment is postponed, and, sometimes there are complications. The most common agents include Neisseria gonorrhoeae, Chlamydia trachomatis, Treponema pallidum and Herpes simplex ${ }^{2,5,6}$. Specific sensitivity lab tests to confirm the diagnosis are essential for the proper treatment, thus avoiding dissemination and sequels ${ }^{7}$. The objective of this article is to bring the attention to STDs in the proctitis etiology, as well as their diagnosis and treatment.

Study carried out at the Technical Team of Proctology at Instituto de Infectologia Emilio Ribas - São Paulo (SP), Brazil.

Financing source: none.

Conflict of interest: nothing to declare.

Submitted on: $08 / 22 / 2011$

Approved on: 10/10/2011 
Proctitis may present in two different forms. In the symptomatic acute form, the patient complains of pain, mucopurulent anal discharge, bleeding and full rectum feeling, or incomplete evacuation. In the moderate or chronic form, the symptoms are less intense and characterized by the presence of mucus in feces, constipation, and, sometimes, feeling of incomplete evacuation ${ }^{4}$. In both cases, they can be taken for idiopathic inflammatory bowel disease ${ }^{8}$.

Proctoscopy is necessary, but not always possible, due to the intensity of the reported anal pain. When performed, it shows mucus or suppuration in the rectum, loss of vascular pattern, edema, friability to the contact of the device, and, sometimes, ulcers or inflammatory tumors, like in syphilis and the venereal lymphogranuloma ${ }^{4,8}$.

Anorectal gonorrhea seems to be more common among youngsters. It may be asymptomatic in many patients, or cause pain and mucopurulent discharge. Rectal touch is painful, and when it is possible, proctoscopy shows enantema, edema, friability and yellowish discharge adhered to the mucosa. The discharge culture is the gold standard test to diagnose Neisseria gonorrhoeae. The presence of gram negative intracellular diplococci is highly suggestive ${ }^{9}$. Due to the frequent association with Chlamidia trachomatis, the recommended treatment should include single doses of $500 \mathrm{mg}$ oral ciprofloxacin and $1 \mathrm{~g}$ azithromycin, or $100 \mathrm{mg}$ doxycycline twice a day, for seven days ${ }^{4}$.

Proctitis by Chlamidia trachomatis is usually moderate; however, it is asymptomatic in $2 / 3$ of the infected patients. Nucleic acid amplification assays are seen as the new gold standard for diagnosis, although culture is still considered as the most specific technique ${ }^{4}$. The treatment can be based on oral $1 \mathrm{~g}$ azithromycin, single dose, or $100 \mathrm{mg}$ doxycycline twice a day, for seven days. When the samples test positive for chlamydia, the L-strains that produce the venereal lymphogranuloma should be analyzed ${ }^{8}$. The proctitis caused by this agent presents increased incidence in western countries, especially among MSM who are positive for HIV ${ }^{10,11}$. The polymerase chain reaction (PCR) in the rectal biopsy detects the Chlamydia DNA, which cannot be identified in the discharge collected with a swab ${ }^{4}$. Symptoms are more intense and macroscopic and histopathological fea- tures are similar to those observed in Crohn's disease $^{4}$. Treatment is based on $100 \mathrm{mg}$ doxycycline twice a day, for 21 days $^{8,11}$.

When proctitis is caused by Treponema pallidum, Haemophilus ducreyi or the Herpes simplex virus, clinical and bacteriological correlation is low; however, we must try and establish the microbiological diagnosis ${ }^{8}$. Primary and secondary lesions of syphilis present with treponema, which can be identified by dark field microscopy. Proctoscopy shows from moderate proctitis to ulcers with elevated borders, being suggestive of tumor ${ }^{4}$. Serologic diagnosis after the primary disease is based on positive non-treponemal tests confirmed by the treponemal tests ${ }^{12}$. Among these, the association of the Veneral Disease Research Laboratory (VDLR) and ELISA or FTA-Abs presents the best cost-benefit $^{12}$. The treatment in the primary stage is based on intramuscular penicillin benzathine $(2.4$ million units). Serum follow-up is necessary for 18 months to make sure the disease is healed ${ }^{12}$.

Chanchroid caused by $H$ ducrey leads to proctitis with multiple and painful ulcers, besides the mucopurulent discharge with bad odor. Gram coloration shows negative cocci designed as coryneforms in the neutrophil cytoplasm. The treatment consists of oral $1 \mathrm{~g}$ azithromycin, single dose $\mathrm{e}^{4}$.

As to herpetic proctitis, it is possible to observe enantema, edema, friability and aphtous ulcers, thus suggesting bowel inflammatory disease ${ }^{2,13}$. The cell culture is considered as gold standard for the Herpes simplex virus, even though immunohistochemical tests have specificity and sensitivity of $100 \%$. Infection is self-limited in immunocompetent patients, but it may persist among the immunocompromised ones, thus requiring a prolonged treatment. This universally accepted strategy ${ }^{13}$; however, $200 \mathrm{mg}$ oral acyclovir, five times a day, or $400 \mathrm{mg}$ three times a day, for five days, may control the symptoms.

Proctitis by cytomegalovirus (CMV) appears after receptive anal sex. It typically presents with rectal bleeding and mononucleosis-like syndrome. The disease is spontaneously healed among immunocompetent patients, but it is associated with the HIV infection ${ }^{3}$.

In places or situations in which it is not possible to obtain the etiological diagnosis, syndromic treatment 
may take place ${ }^{8}$. A single dose of $250 \mathrm{mg}$ intramuscular ceftriaxone is prescribed, associated with a single dose of $1 \mathrm{~g}$ oral azithromycin, or $100 \mathrm{mg}$ oral doxycycline twice a day for seven days. If there is association with fever, paresthesia in the innervation territory of the caudal nerve or urinary symptoms, $200 \mathrm{mg}$ oral acyclovir five times a day, or $500 \mathrm{mg}$ oral valacyclovir twice a day, for 5-10 days ${ }^{4}$.

\section{REFERENCES}

1. Van Kemseke C. Sexually transmitted diseases and anorectum. Acta Gastroenterol Belg 2009;72(4):413-9.

2. Hoentjen F, Rubin DT. Infectious proctitis: when to suspect it is not inflammatory bowel disease. Dig Dis Sci 2011. [Epub ahead of print].

3. Davis TW, Goldstone SE. Sexually transmitted infections as a cause of proctitis in men who have sex with men. Dis Colon Rectum 2009;52(3):507-12.

4. McMillan A, Van Voorst Vader PC, de Vries HJ; International Union against Sexually Transmitted Infections/World Health Organization. The 2007 European Guideline (International Union against Sexually Transmitted Infections/World Health Organization) on the management of proctitis, proctocolitis and enteritis caused by sexually transmissible pathogens. Int J STD AIDS 2007;18(8):514-20.

5. Voth ML, Akbari RP. Sexually transmitted proctitides. Clin Colon Rectal Surg 2007;20(1):58-63.

6. O'Farrell N, Morison L, Moodley P, Pillay K, Vanmali T, Quigley M, et al. Genital ulcers and concomitant complaints in men attending a sexually transmitted infections clinic: implications for sexually transmitted infections management. Sex Transm Dis 2008;35(6):545-9.

7. Vázquez F, Lepe JA, Otero L, Blanco MA, Aznar J.
It is important to consider these diseases when formulating the differential diagnosis of proctitis, in order to identify and treat them and to avoid their dissemination, as well as the HIV infection, which requires continuous lesions to enter the body and cause the disease. Anti-HIV, syphilis and hepatitis B and C serologies should be required due to the association between different STDs.

Microbiological diagnosis of sexually-transmitted infection (2007). Enferm Infecc Microbiol Clin 2008;26(1):32-7.

8. Hamlyn E, Taylor C. Sexually transmitted proctitis. Postgrad Med J 2006;82(973):733-6.

9. Hunte T, Alcaide M, Castro J. Rectal infections with chlamydia and gonorrhoea in women attending a multiethnic sexually transmitted diseases urban clinic. Int J STD AIDS 2010;21(12):819-22.

10. Vall-Mayans M, Caballero E. Lymphogranuloma venereum: an emerging cause of proctitis in homosexual men in Barcelona. Rev Clin Esp 2009;209(2):78-81.

11. Hernani BL, Nadal SR. Linfogranuloma venéreo: aumento da incidência sugere surto mundial da doença. Rev Bras Coloproct 2007;27(2):224-7.

12. Nadal SR, Framil VS. Interpretação dos exames de sorologia para diagnóstico e seguimento pós-terapêutico da sífilis. Rev Bras Coloproct 2007;27(4):479-82.

13. Lavery EA, Coyle WJ. Herpes simplex virus and the alimentary tract. Curr Gastroenterol Rep 2008;10(4):417-23.

\section{Correspondence to:}

Sidney Roberto Nadal

Rua Mateus Grou, 130, Pinheiros

CEP: 05415-040 - São Paulo (SP), Brazil

E-mail: srnadal@terra.com.br 